\title{
International seminar: Good practices in oral history methodology, March 4th-5th 2013, Liberec
}

Wroctawski Rocznik

Na początku marca 2013 r. w Libercu w Republice Czeskiej miało miejsce międzynarodowe seminarium z zakresu historii mówionej. Jego głównym pomysłodawcą i koordynatorem była pozarządowa organizacja Liberecká občanská společnost (Liberecka społeczność obywatelska). Wydarzenie to stało się dobrą okazją, aby zaprezentować doświadczenia różnorakich projektów, w których historia mówiona została użyta jako główne narzędzie badawcze. Podczas dwóch dni obrad swoje inicjatywy zaprezentowali przedstawiciele różnych dyscyplin i środowisk z Czech, Polski, Niemiec i Austrii. Miejscem obrad była położona w centrum Liberca biblioteka miejska oraz funkcjonująca w kompleksie tego budynku synagoga.

Refleksja nad praktyką historii mówionej nie byłaby sensowna bez namysłu metodologicznego. Te dwa wątki przewijały się jako wiodące podczas całej konferencji. Jako pierwszy zabrał głos profesor Miroslav Vanĕk. W wykładzie o tytule How to make oral history better? przedstawił doświadczenie czeskie z historią mówioną. Profesor Vaněk, były przewodniczący International Oral History Association, nawiązał do swoich badań z zakresu historii najnowszej, skupionych na latach siedemdziesiątych i osiemdziesiątych XX w. w kontekście wykorzystania wywiadów ze świadkami historii. W swojej prezentacji pokrótce przedstawił również rozwój zainteresowania historią mówioną w Czechach, jak i wskazał kilka błędów, jakie zwykle popełnia osoba prowadząca wywiad. 
Kolejne wystąpienia seminaryjne miały charakter prezentacji wybranych projektów ze szczególnym uwzględnieniem metod historii mówionej. Georg Traska $\mathrm{z}$ austriackiego Institut für historische Intervention, zaprezentował wystawę oraz audio przewodnik na temat społeczności żydowskiej w Wiedniu przed II wojną światową. Mówiąc o nim, szczególną uwagę zwrócił na nagrania wideo $\mathrm{z}$ wywiadami ze świadkami historii. Referent podkreślił fakt rozmieszczenia przystanków na trasie turystycznej i ich różnorodności oraz dostępność do wywiadów w pięciu językach, w tym tureckim i serbsko-chorwackim - językach dominujących grup emigrantów.

Michał Louc z Ratenic w Czechach pokazał działania stowarzyszenia Ratenicka Vcela (Pszczoła) pracującego na rzecz integracji i rozwoju mieszkańców miasta. Historia mówiona była głównym narzędziem do przeprowadzenia projektu Living history in Ratenice, mającego za zadanie przekazać mieszkańcom w postaci wywiadów kulturalne dziedzictwo miasta oraz najnowszą historię.

Projekt dotyczący innego miasta, Warszawy, zaprezentowała Anna Czyżewska ze Stowarzyszenia Pracownia Etnograficzna. Miejska ścieżka to oferta skierowana głównie do turystów, którzy poprzez ściągnięcie pliku i nałożenie słuchawek mogą wysłuchać historii mieszkańców stolicy Polski, a tym samym zbliżyć się do ich codziennego życia, problemów i miejsc, w których przebywają.

Inicjatywę dotyczącą innej stolicy omówił Tim Kölner z Institut für angewandte Geschichte. Dotyczyła on Berlina jako miasta, które przez lata przedzielone było murem i kategoryzowane na wschodni oraz zachodni. Studenci w projekcie Die Grenzreporter przeprowadzali wywiady z ludźmi, dla których podział i życie w cieniu muru było codziennością.

Maria Novotnă z organizacji Post Bellum z Pragi przedstawiła aplikację na telefon Memory of Nations. Założeniem tej inicjatywy jest poznawanie różnych miejsc w Czechach i ich najnowszej historii za pomocą aplikacji na system Android. Poprzez pobranie takiego pliku na telefon możliwe jest odsłuchiwanie relacji świadków historii.

Przedstawicielka organizacji People in Need, Nadia Aliova, zaprezentowała program nauczania historii powojennej oparty na historii mówionej. Jego założeniem jest umożliwienie szkołom, a zwłaszcza uczniom, spotkania ze świadkami historii oraz samodzielne przeprowadzenie wywiadu. Dzięki temu wiedza uczniów może być uzupełniona o nieznane dotąd fakty, a rozmowa z uczestnikami wydarzeń sprzed lat powinna jeszcze mocniej wpłynąć na chęć poznania dziejów. Podobny projekt dotyczący aktywno- 
ści uczniów w rozmowach ze świadkami historii przedstawiła Magdalena

Benešovă z organizacji Post Bellum. W prezentacji Our Neighbour's Stories młodzież poprzez prowadzenie wywiadów poznaje swoją okolicę, małą ojczyznę, a tym samym uczy się najnowszej historii Czech. Zaprezentowała również, jak można poprzez konkretny wywiad dotrzeć do młodzieży, posługując się formą komiksu.

Piotr Dobosz przedstawił z kolei projekt Centrum Inicjatyw Unesco z Wrocławia o nazwie Obojętność boli. Dotyczy on doświadczenia Holocaustu i relacji między Sprawiedliwymi wśród Narodów Świata a ocalonymi z Zagłady. Celem tej inicjatywy było stworzenie trzech ścieżek lekcyjnych dla młodzieży w wieku gimnazjalnym i licealnym. Ich zadanie to przedstawienie nie tylko zawiłych losów czasu wojny, lecz także pokazanie skomplikowanych relacji mieszkańców Dolnego Śląska. Poprzez relację świadków, głównie Sprawiedliwych, młodzież uczestnicząca w programie może zrozumieć czym był Holocaust.

Drugi dzień seminarium zainicjowała Barbara Kintaert. Przedstawiła ona projekt 1938 Adresse: Servitengasse, dotyczący jednej z wiedeńskich ulic, która jeszcze przed II wojną światową w przeważającej części była zamieszkana przez Żydów. Skupiając się na konkretnej kamienicy, uczestnicy projektu zrekonstruowali listę przedwojennych lokatorów. Dotarli do wciąż żyjących i przeprowadzili z nimi wywiady. Te oraz wiele innych inicjatyw dotyczących ulicy pozwoliło upamiętnić także tych mieszkańców, którzy zginęli w Zagładzie. Działania uczestników projektu doprowadziły do przywrócenia pamięci o dawnym charakterze tej ulicy, a tym samym zachęciły obecnych mieszkańców do większej integracji.

Inicjatywę dotyczącą Żołnierzy Armii Krajowej zaprezentował Grzegorz Kowal z wrocławskiego Ośrodka „Pamięć i Przyszłość”. Projekt o nazwie Tramwaj Wolności skupiał się na prezentacji w komunikacji miejskiej fragmentów wywiadów z żołnierzami Armii Krajowej. Ciekawe cytaty z tych rozmów można było przeczytać w jednej z linii tramwajowych podczas codziennych przejazdów do pracy czy szkoły.

Z kolei Susanne Gärtner z Instytutu Herberta Wehnera oraz Fundacji Brücke/Most z Drezna przedstawiła program seminariów organizowanych w Polsce, Czechach oraz Niemczech. Uczestnicy tych spotkań mogą poznać historię i zwyczaje sąsiadów z zagranicy, a także porozmawiać na temat trudnych dziejów powojennych graniczących ze sobą ziem.

Robert Maciąg ze Stowarzyszenia Dobków zaprezentował z kolei swoją książkę Dobków: Wyspa. Dotyczy ona historii mieszkańców małej wioski 
w Górach Kaczawskich, którzy zechcieli podzielić się z autorem swoimi historiami. Temat rozmów odnosi się szczególnie do dziejów kilku lat powojennych, kiedy na tych terenach nastąpiła zupełna zmiana ludności. Książka jednak była pretekstem dla Maciąga do opowiedzenia swoich doświadczeń z historią mówioną. Pisarz na swoim przykładzie przedstawił główne pułapki, w jakie może wpaść osoba prowadząca wywiad, jak i podzielił się nad wyraz cennymi uwagami co do opracowywania wywiadów.

Jako następny prelegent Kai Kranich zaprezentował swój autorski program oparty nie tyle na wywiadach, ile fotografii. Odnosił się on do problemu „zaginionych miejsc” na Dolnym Śląsku, które powoli znikają z krajobrazu dzisiejszych wsi i miasteczek.

Zupełne inne ujęcie historii mówionej pokazała zaś Katarzyna Kuzko-Zwierz, prezentując projekt z Warszawskiego Muzeum Pragi. W tej oryginalnej inicjatywie pracownicy muzeum na podstawie wywiadów spróbowali oddać dawne dzieje zachodniej dzielnicy stolicy Polski ze szczególnym uwzględnieniem zmysłów. Dzięki temu można usłyszeć o częściach Pragi, które kusiły mieszkańców swoimi smakami, np.: związanymi z wędliniarnią czy zapachami unoszącymi się z fabryki czekolady. Dzięki naniesieniu tych wspomnień na mapę autorzy uzyskali ciekawy, „zmysłowy” obraz dzielnicy.

Pod koniec obrad Michal Bureš zaprezentował harcerskie doświadczenie z historią mówioną w Czechach. Poprzez ten projekt harcerze wewnątrz swojego środowiska mogli nie tylko dotrzeć do pasjonujących historii starszych druhów, co poznać dzieje swojej organizacji i narodu.

Ostatnim wystąpieniem seminaryjnym była prezentacja Agaty Zysiak z Łodzi. Dotyczyła ona projektu mającego na celu „opowiedzieć miasto”, którego wynikiem jest witryna www.miejscownik.org. Autorzy zrealizowali zadanie przedstawienia miasta we wspomnieniach jego mieszkańców. Według tej inicjatywy przestrzeń miejską można eksplorować poprzez konkretne instytucje czy ulice. Dodatkowo autorzy, realizując poszczególne zadania, uczyli się metod związanych z przeprowadzaniem wywiadów. Pokłosiem tych prób jest podręcznik Historie Mówione.

Niniejsze seminarium pokazało, jak różnorodnie można używać historii mówionej oraz jak liczne są organizacje czy środowiska, które stosują takie metody. Nad wyraz cenna była prezentacja projektów angażujących uczniów. Ci, poprzez uczestnictwo w takim programie, mają nie tylko okazję do poznania historii mówionej, lecz także sposobność do nawiązania nowych relacji, poznania historii swojego kraju oraz środowiska. Prelegenci 
w większości przypadków prezentowali również swoje osobiste doświadczenia z przeprowadzania wywiadów, co dla słuchaczy było dużym zbiorem porad i cennych uwag. Z pewnością zestawienie wszystkich tych „dobrych praktyk" w zwartej formie byłoby wartościowym uzupełnieniem warsztatu dla osób rozpoczynających swoje zmagania z pracą nad wywiadami. Warty podkreślenia jest też fakt połączenia $\mathrm{w}$ seminarium kręgów naukowo zajmujących się metodą oral history oraz organizacji pozarządowych, stowarzyszeń, które konkretnie potrafią ją wykorzystać w codziennej pracy. Równie cenne jest, że seminarium towarzyszyła Human Library (Żywa biblioteka), czyli możliwość wysłuchania świadków historii, którzy opowiadali o życiu w czasie rządów komunistów w Czechach czy o osobistym doświadczeniu Liberca. Taka inicjatywa otwarta dla wszystkich chętnych była możliwością doświadczenia, czym rzeczywiście jest historia mówiona. 